\title{
The Role of Hypnotherapy in The Process of Reducing Anxiety Among The Injured Athletes
}

\author{
M. Erika Rachman ${ }^{\bowtie}$, Agus Kristiyanto, Tri Aprilijanto Utomo \\ Universitas Sebelas Maret, Surakarta, Indonesia
}

\begin{abstract}
This research aimed to find out the role of hypnotherapy in the process of reducing anxiety among the injured athletes. This research was conducted on Jerry Lolowang as the main informant using paradigm and qualitative method, to result in a comprehensive understanding on the phenomenon studied. Specifically, this qualitative research employed case study research design - Life History. Four criteria were used: credibility, transferability, dependability, and confirmability. Data validation was carried out using data triangulation on the informant considered as close to Jerry Lolowang. The analysis in this research was conducted in four stages: data collection, data reduction, data display, conclusion verification. The result of interview with Jerry Lolowang as the basketball athlete who has ever been injured or sick showed that hypnotherapy is one way of decreasing anxiety during injury or illness. Cancer is a set of diseases characterized with uncontrolled growth of certain body cell leading to cell damage and other body tissues, and cancer can affect everyone including athletes. Hypnotherapy can help the process of reducing anxiety and curing other medical diseases such as cancer, by improving an individual's life spirit to always think positively, and not afraid of his injury in order to improve his body immunity in dealing with his injury.
\end{abstract}

Kata Kunci:

Athlete, Anxiety, Cancer,

Hypnotherapy

(C) 2019 Universitas Pendidikan Indonesia

Alamat korespondensi:

eISSN: 2549-6360

Universitas Sebelas Maret, Surakarta

E-mail: erikrach8@gmail.com 


\section{INTRODUCTION}

Hypnotherapy is an application of hypnosis science used to cope with a variety of psychological problems such as trauma, phobia, self-empowerment, and motivation and to change negative (addicted) behavior, and etc. When connected to physical/medical diseases, theoretically hypnotherapy can only cure the psychosomatic disease only and can help cure other medical diseases such as cancer and AIDS by improving the patients' life spirit in order to improve their body immunity.

Treatment with hypnotherapy can be effective because there is communication pattern and in the communication itself there are communicative elements such as source, message, receiver, effect, media, feedback, and noise or constraint. In communication, a message delivered by communicator to communicant likely encounters constraint in certain condition in the process of sending or receiving message. Pattern is defined as a fixed form or structure, while communication is the process of sending or receiving message between the self and two or more individuals appropriately so that the message intended can be understood. Clients undertaking hypnotherapy treatment through a well-designed and wellplanned communication pattern are expected to cure and even to change their clients' behavior into the better one or the expected one.

Hypnotism is a science that can be explained using modern psychology as it studies how to understand the work mechanism of mind and to use potential thinking and suggestion for many purposes, so that hypnotism now becomes interesting so that there is hypnotic treatment with hypnotherapy through suggestion therapy registered officially in health service and district attorney so that the community will undertake hypnotherapy treatment more comfortably. Considering the background above, the problem statement of research in this research is "The Role of Hypnotherapy in the Process of Reducing Anxiety in the Injured or Sick Athletes.

It becomes a phenomenon, recalling the importance of Jerry Lolowang's journey and struggle as the athlete and captain of Satya Wacana basketball team who has ever been injured or sick and now can play again professionally after having undertaken therapy and treatment. Based on the problem, the objective of research is to get information indepth about the role of hypnotherapy in the process of reducing anxiety in Jerry Lolowang who develops cancer.

Cancer is a disease due to abnormal growth of body tissue cells into cancer cell. In its development, these cancer cells can spread to other body parts, thereby resulting in death and cancer disease is now the leading cause of death throughout world (Hendry, N. 2007).

Cancer survivor is a cancer patient who is in treatment phase or has passed through cancer therapeutic treatment. Cancer survivor may deal with new problem such as their potentially disorganized personal relation, fatigue along the time, anxiety about symptom, treatment, and disease. Some cancer survivors are psychologically paralyzed with their fear of recurrent or worsening cancer disease threat (Sarafino, 2011). Cancer therapy can be conducted with medical and non-medical therapies. Medical therapy is conducted through surgery, radiation/radiotherapy, chemotherapy, immunotherapy, and genetic therapy (Sunaryati, 2011). Non medical therapy is conducted through alternative therapy hypnotherapy and religious therapy.

Chemotherapy is cancer treatment using drugs or medicines. Chemotherapy can spread throughout body and kill cancer cells everywhere inside body. But, chemotherapy can also harm the normal and healthy cells, particularly those in mouth layers and gastrointestinal system, bone marrow and hair pouch (Kelvin and Tyson, 2011). The side effects of chemotherapy, among others, are hair fall or even baldness, bone marrow disorder including reduced hemoglobin, thrombocyte, and leukocyte, limpness, fatigue, narrow breath, hemorrhage and infection, bluish/blackish dry and itchy skin, sprue in the mouth and throat, dry mouth and swallowing difficulty, nausea and vomit, gastrointestinal tract disorder (pain), and impaired hormone production thereby reducing sexual passion and fertility (Bakhtiar, 2012).

Patients undertaking chemotherapy for the first time often overestimate its hazard and underestimate self-ability. They usually have anxiety or fear of chemotherapy before 
undertaking chemotherapy (Desen, 2011). Fear cannot actually be distinguished from anxiety because individuals feeling fearful or anxious will develop behavioral, physiological and emotional response patterns in the same interval. Fear is finding out that there is a threat, while anxiety is the emotion resulting from the fear feeling (Videbeck, 2008).

Anxiety is an individual's emotional agitation related to something external to him/herself and self-mechanism used in solving problem (Asmadi, 2009). Anxiety is an unpleasant and unjustifiable fear frequently accompanied with physiological symptoms, while anxiety disorder contains meaningful anguish and dysfunction due to anxiety (Tomb, 2004). The management of anxiety can be done by means of pharmacology and non-pharmacology. In pharmacology, antianxiety drug, particularly benzodiazepine, is used in short term rather than in long term because this treatment has tolerance and addiction characteristics. Non-pharmacology treatment is conducted through relaxation practice, and psychotherapy particularly using psychodynamics or hypnosis or hypnotherapy (Isaacs, 2005).

Hypnotherapy is one branch of psychology studying the advantage of suggestion to deal with mind, feeling and behavior problems. Hypnotherapy can also be said as a mind and curing therapy technique using hypnotic method to give positive suggestion or instruction to subconscious mind to heal a psychological disorder or to change mind, feeling, and behavior into the better one (Gunawan, 2008).

Hypnotherapy can also be used to recover athletes from their injury or illness as hypnotherapy speeds up a patient's recovery. It is very possible because hypnotherapy is directed to improve body immunity and to reprogram individuals' attitude to disease they develop by means of thinking positively, optimistically, vigorously, happily and without fear of their injury or illness (Susilo, 2010).

\section{METHOD}

This research employed a descriptive qualitative research approach. Particularly, this qualitative research employed case study research - Life History. Case study is a more appropriate strategy when the problem of research is related to "how" and "why" and when the research focuses on the real life context (Yin, Robert K. 2011). This qualitative approach is intrinsic in nature, the research conducted due to interestedness in or caring about a case, aiming to understand the case comprehensively, without intended to result in concept or theory (Poerwandari, Kristi, 2005). In this case, the author participated in the process of expressing relation-reflective experiences with enlivening, delivering, rekindling, and presenting again the life story.

Data of research was collected from the result of interview, while data source was obtained from main informant (Jerry Lolowang) and the informant considered as capable of giving adequate information related to this research. In this research, data collected was divided through six sections: data source and type, human as instrument and participatory observation, observation, interview, field note, and document use. There were four criteria used: credibility, transferability, dependability, and confirmability. Data analysis was conducted in four stages: (1) data collection, (2) data reduction, (3) data display, and (4) conclusion drawing.

Interview was carried out using interview guide as the outline of anything should be asked to the interviewee. This technique of collecting data through interview aims to obtain in-depth information about the role of Hypnotherapy in the process of reducing anxiety among athletes developing injury or illness. Thus, in this research, the data was obtained from:

1. Jerry Lolowang as cancer survivor and national basketball player

2. Jerry Lolowang's family

3. Jerry Lolowang's coach

4. Jerry Lolowang's physician team

5. Jerry Lolowang's teammates

The information was selected to answer the questions provided by the author.

\section{RESULT AND DISCUSSION}

Considering data analysis and discussion conducted with some informants, the following results can be obtained: The role of hypnotherapy in the process of reducing anxiety among injured and sick athletes includes some important aspects: high ability, self conviction, self confidence, persistence, 
positive thinking, champion mentality, and hypnotherapy.

High willingness and self conviction result from injury and illness suffered from, so that Jerry has high willingness to be recovered from his illness and to play basketball again, with self conviction to resist injury or illness he suffers from. Jerry wants to show it to everyone supporting him so far. To Jerry, money is not everything, but living beneficially to others is very useful later.

These persistence and positive thinking generates optimism in Jerry to achieve an objective of being cured and the best. Persistence and high positive thinking lead him to have resistance and spirit to deal with his injury and illness situations; he always thinks that he can pass through this injury or illness without thinking negatively of the injury and illness; everything can be solved despite very hard challenge. Even, Jerry has never been afraid of situation replete with tension or confusion in dealing with something that can threat him. Jerry believes that he is able, he is strong, and he is vigorous; that is the fact he has, Jerry's belief continues and becomes reality by itself. Persistence and positive thinking characteristics that Jerry Lolowang has are very prominent in his struggle as cancer survivor in attaining the national basketball achievement. It can be seen from the result of interview, research and discussion conducted by the author with Jerry Lolowang.

Champion mentality that Jerry has makes him the athlete with self conviction, high achievement, consistency to achieve objective, positive thinking, open mind, good selfcontrol, discipline, responsibility, ability of setting out the goal, of adapting to his environment, perseverance, diligence, innovativeness, sportsmanship, and wisdom. Jerry's champion mentality is affected by such factors as high self-confidence to pass through his injury and illness period, expectation to be recovered from his cancer disease and to be health again, self-control not to do unexpected deed, focusing on the bright future, dealing with the difficult challenging situation calmly, being productive and thinking positively to be recovered from his disease, strong determination and commitment to be recovered and to show it to everyone supporting him so far.

Hypnotherapy is beneficial to recover the athletes from their injury or illness because it is a mind and healing therapy technique using hypnotic method to give positive suggestion or instruction to subconscious mind to heal a psychological disorder or to change mind, feeling, and behavior into the better one because it is directed to improve body immunity and to reprogram individuals' attitude to disease they develop by means of thinking positively, optimistically, vigorously, happily and without fear of their injury or illness.

\section{CONCLUSION}

Considering data analysis and discussion conducted, it can be concluded that hypnotherapy contributes to reducing anxiety level in Jerry Lolowang, a national basketball athlete who has ever developed injury or cancer disease and undertaken chemotherapy. Hypnotherapy is beneficial to recover the athletes from injury or illness, by means of giving positive suggestion or instruction to subconscious mind to heal a psychological disorder or to change mind, feeling, and behavior into the better one because it is directed to improve body immunity and to reprogram individuals' attitude to disease they develop by means of thinking positively, optimistically, vigorously, happily and without fear of their injury or illness.

Further researchers are expected to conduct other studies on the role and benefit of hypnotherapy viewed from other aspects and sectors.

\section{BIBLIOGRAPHY}

Asmadi. (2008). Kebutuhan Dasar Manusia. Jakarta: Salemba Medika.

Bakhtiar. (2012). Manfaat \& Efek Samping Kemoterapi. Jogjakarta: Flamingo.

Desen, W. (2011). Buku ajar Onkology Klinis (ed 2). Jakarta: FK-UI

Gunawan A. W. (2007). HYPNOTHERAPY The Art of Subconscious Restructuring. Jakarta: Gramedia Pustaka Utama 
Hendry, N. (2007). Pencegahan dan Terapi Kanker. Jakarta: Balai

Isaacs, Ann. (2005). Buku Panduan Belajar Keperawatan Kesehatan Jiwa dan Pskiatrik edisi 3. Jakarta: EGC

Kelvin J. F. dan Tyson, L. B. (2011). 100 Tanya-Jawab Mengenai Gejala Kanker dan Efek Samping Pengobatan Kanker. Jakarta : PT-Indeks.

Poerwandari, Kristi. (2005). Pendekatan Kualitatif Untuk Penelitian Perilaku Manusia. Depok: Lembaga Pengembangan Sarana Pengukuran dan Pendidikan Psikologi (LPSP3).

Sarafino, Edward P., Timothy W. Smith. (2011). Health Psychology Biopsychosocial Interactions Seventh edition. United States of America.

Sunaryati, Septi Shinta. (2011). 14 Penyakit Paling Sering Menyerang dan Sering Menyerang dan Sangat Mematikan. Yogyakarta: Flashbooks.

Susilo, A., \& Kemala, E. (2010). Hipnotis Metode Terapi Untuk Kesuksesan Karier dan Menghilangkan Kebiasaan Buruk dengan Hipnoterapi. Editor:Dini handayani. Jakarta : Gudang Ilmu.

Tomb. (2004), Buku Saku Psikiatri, Penerbit buku kedokteran EGC, jakarta

Videbeck, S.J., (2008), Buku Ajar Keperawatan Jiwa, Jakarta : EGC

Yin, Robert K. (2011). Studi Kasus Desain dan Metode. Jakarta: Raja grafindo: Persada. 